\title{
Depletion of an Artificial Weed Seed Bank during the Dormant Period via Heating and Subsequent Chilling of Soil
}

\author{
Rakesh S. Chandran ${ }^{1}$ and Megh Singh ${ }^{2}$ \\ University of Florida, Institute of Food and Agricultural Sciences, Citrus \\ Research and Education Center, 700 Experiment Station Road, Lake Alfred, \\ FL 33850-2299
}

Additional index words. nonchemical weed control, johnsongrass, Sorghum halepense, hemp sesbane, Sesbania exaltata, barnyardgrass, Echinochloa crus-galli

\begin{abstract}
Depletion of the weed seed bank by stimulating germination during winter months and subsequently exposing the seedlings to adverse air temperatures is a possible means of controlling weeds in small-scale horticultural operations. Johnsongrass [Sorghum halepense (L.) Pers.], hemp sesbania [Sesbania exaltata (Raf.) Rydb. ex A.W. Hill], and barnyardgrass [Echinochloa crus-galli (L.) Beauv.] were seeded in soil trays and maintained for 4 days at 4 or $-12{ }^{\circ} \mathrm{C}$, then heated to $32^{\circ} \mathrm{C}$ for 4 days using electric heating pads. Germination percentages, after heating soils, were: $55 \%$ and $70 \%$ for hemp sesbania, $82 \%$ and $72 \%$ for barnyardgrass, and $45 \%$ and $55 \%$ for johnsongrass, respectively; for seeds kept at -12 and $4{ }^{\circ} \mathrm{C}$, respectively. Subsequent exposure of seedlings to $-12{ }^{\circ} \mathrm{C}$ for 7 days killed all seedlings, while exposure to $4^{\circ} \mathrm{C}$ killed only $18 \%$ to $28 \%$. The temperature regimes of $-12{ }^{\circ} \mathrm{C}$ for 4 days, and $32{ }^{\circ} \mathrm{C}$ for 4 days followed by $-12{ }^{\circ} \mathrm{C}$ killed $95 \%, 78 \%$, and $68 \%$ of the johnsongrass, hemp sesbania, and barnyardgrass, respectively.
\end{abstract}

Preventive measures to control weeds before crop seeding or emergence are of particular interest to growers. Although weed life cycles have been exploited historically in weed management strategies, Bhowmik (1997) and Norris (1997) have recently stressed the importance of seed biology in weed management. Bhowmik emphasized the development of environmentally safe weed management systems, while Norris, based on a survey, predicted an increase in importance of weed seed dynamics in the future.

The top $10-15 \mathrm{~cm}$ of soil contains viable seeds, which germinate under suitable conditions, or after breaking dormancy. Seed bank sizes have been estimated at $\approx 1$ million seeds $/ \mathrm{m}^{2}$ under dense infestations (Fenner, 1985). Of the 2 million seeds produced by a single horseweed [Conyza canadensis (L.) Cronq.] plant in a no-till site, $\approx 80 \%$ of the total germinable seeds were found within the top $2 \mathrm{~cm}$ of soil (Bhowmik and Bekech, 1993).

Received for publication 17 May 1999. Accepted for publication 16 Feb. 2000. Florida Agricultural Experiment Station Journal Series No. R-06213. The cost of publishing this paper was defrayed in part by the payment of page charges. Under postal regulations, this paper therefore must be hereby marked advertisement solely to indicate this fact. ${ }^{1}$ Post-Doctoral Research Associate. Current address: Extension Specialist-IPM and Research Assistant Professor, 1076 Agricultural Sciences Building, West Virginia University, Morgantown, WV 26506-6108. E-mail address: rchandr2@ wvu.edu

${ }^{2}$ Professor species was $\geq 90 \%$ based on petri-dish germination tests. Galvanized trays $(55 \times 40$ $\mathrm{cm}, 12 \mathrm{~cm}$ deep) were filled with moist soil from the upper $30 \mathrm{~cm}$ of a Candler fine sand (hyperthermic, uncoated Typic Quartzipsamment; organic matter content $1.2 \%, \mathrm{pH}$ 6.3). Soil moisture was brought to $22 \%$ (dry weight basis) by adding known volumes of water per unit volume of sand. Fifty seeds each of johnsongrass, hemp sesbania, and barnyardgrass were placed in six rows on either the soil surface or at $2.5 \mathrm{~cm}$ depth in each tray.

Expt. 1. The effect of seed exposure to low temperatures on subsequent germination was determined in a preliminary study. Seeded trays were transferred either to 4 or $-12{ }^{\circ} \mathrm{C}$, respectively, or to a greenhouse $\left(32{ }^{\circ} \mathrm{C}\right.$ day $/ 25^{\circ} \mathrm{C}$ night). Cold room-treated trays were transferred to the greenhouse $7 \mathrm{~d}$ later and seedling counts were recorded upon germination.

Expt. 2. For the main experiment, seeded trays were held in the greenhouse (control, $32{ }^{\circ} \mathrm{C}$ day $/ 25^{\circ} \mathrm{C}$ night), or at 4 or $-12{ }^{\circ} \mathrm{C}$. In each cold room, the trays were subjected to three successive temperature regimes. In the first regime, the soil temperature at a depth of $2.5 \mathrm{~cm}$ was allowed to equilibrate to the ambient temperature $\left(4\right.$ or $\left.-12{ }^{\circ} \mathrm{C}\right)$, and the trays were monitored for germination for an additional $4 \mathrm{~d}$. After recording germination counts, if any, electric heating pads (Low Watt Propagation Heating Mat; Olson Products, Medina, Ohio) were placed directly on top of the trays, after ensuring proper contact with the soil surface. The heating pad thermocouple sensor was placed at a depth of $2.5 \mathrm{~cm}$, and was calibrated to maintain a soil temperature of 32 ${ }^{\circ} \mathrm{C}$ at this depth. A 1-cm-thick insulating material, made of polyisocyanurate foam with aluminum foil on both sides (Tuff-R insulating sheathing; The Celotex Corp., Fremont, Calif.), was placed over the heating pad to minimize convective heat loss. The heating pads were removed after a period of $4 \mathrm{~d}$ and germination counts were recorded for each seeding depth, in situ. Following heating, the trays remained in the cold rooms for an additional $7 \mathrm{~d}$.

At the end of the 7-d period, trays were transferred to the greenhouse, irrigated, and seedling survival was quantified by counting actively growing seedlings 1 week later. Trays were irrigated to field capacity on a daily basis, and counted seedlings were removed by hand. Trays were maintained in the greenhouse for an additional 2-week period to allow germination of additional seeds. Weed counts in control trays were taken at the same time intervals as temperature treatments. The two counts ( 1 and 3 weeks) were added and the sum was divided by the total that had germinated in trays maintained continuously in the greenhouse. Germination data were expressed as a percentage of the control.

All treatments were replicated four times in a randomized complete-block design. Data were subjected to analysis of variance (ANOVA) and treatment means separated by least significant difference (LSD) at $P \leq 0.05$. The study was repeated and data from the two
All weed seeds used in the study were obtained from a commercial seed company (Valley Seeds, Fresno, Calif.), and were stored in a refrigerator at $4{ }^{\circ} \mathrm{C}$ prior to initiation of the study. Minimum germination of weed 
studies were pooled after performing a test of homogeneity of variance.

\section{Results and Discussion}

Expt. 1. Exposure of weed seeds to 4 or $-12{ }^{\circ} \mathrm{C}$ for $7 \mathrm{~d}$, followed by transfer to greenhouse $\left(32 / 25^{\circ} \mathrm{C}\right)$ reduced subsequent germination percentage of hemp sesbania and johnsongrass, relative to that of control seeds maintained in the greenhouse (Table 1). However, germination percentage of barnyardgrass was not reduced. This may indicate that cold treatment of hemp sesbania and johnsongrass seed induced them into secondary dormancy. Also, some seeds may have been killed as a result of the cold treatment. We did not further investigate these possibilities since they were beyond the scope of experimental objectives. The effects of high and low temperatures on secondary dormancy induction in weed seeds are discussed by other researchers (Dubey and Mall, 1972; Fischer et al., 1982; Twentyman, 1974).

Expt. 2. Seeds of all species exposed to 4 or $-12^{\circ} \mathrm{C}$ for $96 \mathrm{~h}$ failed to germinate under cold room conditions (data not shown). Although some seeds on the soil surface showed signs of germination under greenhouse conditions, $>90 \%$ of the seedlings failed to become established (data not shown). This may be attributed to lack of sufficient uptake of water from the surface layer because of the absence of a well-developed root system.

Heating soils to $32{ }^{\circ} \mathrm{C}$ for $96 \mathrm{~h}$ in the cold room resulted in germination of the buried seeds (Table 2). No statistical differences were observed in seedling emergence at 4 vs. $-12{ }^{\circ} \mathrm{C}$. Emergence following heat treatment for seeds held at 4 and $-12{ }^{\circ} \mathrm{C}$ was $70 \%$ and $55 \%$ of the control for hemp sesbania, $72 \%$ and $82 \%$ for barnyardgrass, and $55 \%$ and $45 \%$ for johnsongrass, respectively. The effects of temperature on germination are well-established (Devlin and Witham, 1983; King and Oliver, 1994; Probert and Black, 1994).

Heating also caused the seeds on the soil surface to germinate, but further growth was retarded. When the heating pads were removed, all seedlings appeared to be etiolated, because of the presence of the opaque heating pad and the insulating material.

After an additional $96 \mathrm{~h}$ of cold treatment, all seedlings exposed to $-12{ }^{\circ} \mathrm{C}$ were killed (Table 2). Although the seedlings exposed to $4{ }^{\circ} \mathrm{C}$ were still alive, growth was minimal. Thus $4{ }^{\circ} \mathrm{C}$ was too low for rapid growth, but not lethal. These results were more distinct after the seedlings were transferred to the greenhouse, where seedlings placed in the cold room at $-12^{\circ} \mathrm{C}$ failed to grow, while those kept at $4{ }^{\circ} \mathrm{C}$ developed some green pigmentation after 2-3 d.

Exposure to $4{ }^{\circ} \mathrm{C}$ resulted in $21 \%$ control of hemp sesbania, $18 \%$ control of barnyardgrass, and $28 \%$ control of johnsongrass from a depth of $2.5 \mathrm{~cm}$. Greenhouse conditions provided adequate sunlight for the etiolated seedlings to develop pigmentation. Death of some seedlings from this treatment was perhaps due to their poor adaptability to cold stress.

Some seeds of all three species subjected to $-12{ }^{\circ} \mathrm{C}$ were viable after the two successive cold treatments (Table 3). About 20\%, 30\%, and $5 \%$ of hemp sesbania, barnyardgrass, and johnsongrass seeds, respectively, failed to germinate following artificial heating. Thus, either the duration of artificial heating was inadequate or physiological or environmental thresholds necessary for seed germination were

not attained. Total germination percentages for trays kept in the greenhouse throughout the study were $82 \%, 102 \%$, and $88 \%$, for hemp sesbania, barnyardgrass, and johnsongrass, respectively (Table 3 ). We speculate that total germination percentage of barnyardgrass seeds exceeding $100 \%$ was a result of counting regenerated seedlings, which may have been partially hand-weeded after initial counts.

Control of germinated seedlings as a result of heating, followed by chilling to $-12{ }^{\circ} \mathrm{C}$, was greatest with johnsongrass ( $95 \%$ ) followed by hemp sesbania (78\%), and barnyardgrass (68\%) (Table 3). Depending upon location and the severity of winter climatic conditions, the topsoil or potting media containing weed seeds experiences temperatures unfavorable for seed germination. Elevating the temperature, as simulated in this laboratory study, promoted seed germination(Table2). The heterogeneous population of the soil seed bank, differences in seed dormancy, and differences in early-season weather make weed control difficult for single-

Table 1. Effect of a 7-d temperature treatment on subsequent weed seed germination within 3 weeks after transfer to a greenhouse $\left(32{ }^{\circ} \mathrm{C}\right.$ day $/ 25^{\circ} \mathrm{C}$ night $)$. Expt. 1 .

\begin{tabular}{lccc}
\hline \hline & \multicolumn{3}{c}{ Species } \\
\cline { 2 - 4 } Temperature regime & Hemp sesbania & Barnyardgrass & Johnsongrass \\
\hline & ---------- Emergence $(\%)$ & ---------- \\
$4^{\circ} \mathrm{C} \rightarrow 32 / 25{ }^{\circ} \mathrm{C}$ & 76 & 92 & 64 \\
$-12{ }^{\circ} \mathrm{C} \rightarrow 32 / 25^{\circ} \mathrm{C}$ & 70 & 90 & 58 \\
$32 / 25^{\circ} \mathrm{C}(\mathrm{Control})$ & 94 & 96 & 80 \\
LSD $(P \leq 0.05)$ & 8 & NS & 14 \\
\hline
\end{tabular}

${ }^{\mathrm{Ns} N o n s i g n i f i c a n t .}$

Table 2. Seedlings emerged under cold room conditions after concomitant heat treatment $\left(32{ }^{\circ} \mathrm{C}\right.$ for $96 \mathrm{~h}$ ) or in a greenhouse, of a soil seeded at $2.5 \mathrm{~cm}$ depth, and seedlings killed after subsequent chilling for $7 \mathrm{~d}$.

\begin{tabular}{|c|c|c|c|}
\hline \multirow[b]{2}{*}{ Temperature regime $^{\mathrm{z}}$} & \multicolumn{3}{|c|}{ Species } \\
\hline & Hemp sesbania & Barnyardgrass & Johnsongrass \\
\hline & ------- & Emergence (\%) & ---------- \\
\hline $4{ }^{\circ} \mathrm{C} \rightarrow 32^{\circ} \mathrm{C}$ & 56 & 68 & 44 \\
\hline$-12^{\circ} \mathrm{C} \rightarrow 32^{\circ} \mathrm{C}$ & 44 & 78 & 36 \\
\hline $32 / 25{ }^{\circ} \mathrm{C}$ (Control) & 78 & 94 & 80 \\
\hline $\operatorname{LSD}(P \leq 0.05)$ & 16 & 16 & 16 \\
\hline & ------- & Mortality $(\%)^{y}$ & ---------- \\
\hline $4^{\circ} \mathrm{C} \rightarrow 32{ }^{\circ} \mathrm{C} \rightarrow 4^{\circ} \mathrm{C}$ & 21 & 18 & 28 \\
\hline$-12^{\circ} \mathrm{C} \rightarrow 32^{\circ} \mathrm{C} \rightarrow-12^{\circ} \mathrm{C}$ & 100 & 100 & 100 \\
\hline $32 / 25^{\circ} \mathrm{C}$ (Control) & --- & --- & --- \\
\hline $\operatorname{LSD}(P \leq 0.05)$ & 10 & 18 & 10 \\
\hline
\end{tabular}

${ }^{2}$ Cold room temperatures (where seeded soils were chilled), concomitant heat treatment temperatures, and reversal to cold room temperatures. Control represents ambient greenhouse temperature $\left(32^{\circ} \mathrm{C}\right.$ day/ $/ 25^{\circ} \mathrm{C}$ night).

yPercentages of emerged seedlings that died after a second cold treatment. Control treatments were not subjected to cold treatment.

Table 3. Effects of exposing an artificial seed bank to greenhouse temperatures $\left(32 / 25^{\circ} \mathrm{C}\right)$ after subjecting the seed bank to three temperature regimes, on residual germination and total germination.

\begin{tabular}{|c|c|c|c|c|c|c|}
\hline \multirow[b]{2}{*}{ Temperature treatment } & \multicolumn{6}{|c|}{ Species } \\
\hline & Hemp sesbania & Barnyardgrass & Johnsongrass & Hemp sesbania & Barnyardgrass & $\begin{array}{l}\text { Johnsongrass } \\
\end{array}$ \\
\hline $4^{\circ} \mathrm{C}$ & 12 & 8 & 8 & $68(32)$ & $76(37)$ & $52(54)$ \\
\hline $32 / 25^{\circ} \mathrm{C}$ (Control) & 4 & 8 & 8 & 82 & 102 & 88 \\
\hline $\operatorname{LSD}(P \leq 0.05)$ & 8 & 10 & 6 & --- & --- & --- \\
\hline
\end{tabular}

${ }^{2}$ Total percentage of germination was calculated as: [(seedlings surviving after second cold treatment + residual germination)/Total number of seedlings germinated in untreated soils $] * 100 \%$. Percentage of control given in parenthesis were calculated as, $\{1-[$ (Seedlings surviving after second cold treatment + Residual germination)/Total number of seedlings germinated in control soils] $\} * 100 \%$. 
tactic management approaches. Heating of the soil may help management efforts by triggering weed emergence and by simulating a homogenous environment for uniform germination. Soil solarization is another heat-mediated technique used to deplete the seed bank; the soil is heated during summer months by using plastic sheets placed on a moist soil to trap the solar radiation (Horowitz et al., 1983), and weed propagules or seedlings are killed as a result of heating them. Soil solarization would be less useful for temperate regions, where duration and intensities of sunlight are inadequate to heat the soils to temperatures required to kill seeds or seedlings.

Based upon electric energy costs of $\$ 0.047$ U.S. per kilowatt hour (Tampa Electric Co., Tampa, Fla.), heating $1 \mathrm{~m}^{2}$ of soil from -12 to $32{ }^{\circ} \mathrm{C}$ for $96 \mathrm{~h}$ would cost $\approx \$ 0.65$, assuming that the heating pads operated continuously. The cost-effectiveness of heating soils artificially during winter months could be a limiting factor for large-scale use. If proven useful for a natural weed seed bank, this method may be suitable only for small-scale, commercial, organic gardening operations or home gardens. This method may also be utilized to deplete weed seeds in potting soils during the winter months. Further research is required to determine the effect on a natural population of weed seeds of artificial heating of topsoil. Studies under controlled conditions are required to further determine the duration of heating and optimum temperature required to maximize peak germination.

\section{Literature Cited}

Bhowmik, P.C. 1997. Weed biology: Importance to weed management. Weed Sci. 45:349-356.

Bhowmik, P.C. and M.M. Bekech. 1993. Horseweed (Conyza canadensis) seed production, emergence, and distribution in no-tillage and conventional-tillage corn (Zea mays). Agronomy (Trends in Agr. Sci.) 1:67-71.

Cavers, P.B. 1983. Seed demography. Can. J. Bot. 61:3578-3590.

Devlin, R.M. and F.H. Witham. 1983. Enzymes, p. 189-201. In: Plant physiology. PWS Publishers, Boston.

Dubey, P.S and L.P. Mall. 1972. Ecology of germination of weed seeds. 1. Role of temperature and depth of burial in soil. Oecologia 10:105-110.

Fenner, M. 1985. Soil seed banks, p. 87-100. In Seed ecology. Chapman and Hall, London.

Fischer, M.L, J.F. Stritzke, and R.M. Ahring. 1982. Germination and emergence of little barley (Hordeum pusillum). Weed Sci. 30:624-628.
Horowitz, M., Y. Regev, and G. Herzlinger. 1983. Solarization for weed control. Weed Sci. 31:170-179.

Huang, W.Z. and A.I. Hsiao. 1987. Factors affecting dormancy and germination of johnsongrass, Sorghum halepense (L.) Pers. Weed Res. 27:112.

Hume, L. and O.W. Archibald. 1986. The influence of a weedy habitat on the seed bank of an adjacent cultivated field. Can. J. Bot. 64:18791883.

King, C.A. and L.R. Oliver. 1994. A model for predicting large crabgrass (Digitaria sanguinalis) emergence as influenced by temperature and water potential. Weed Sci. 42:561-567.

Norris, R.F. 1997. Weed Science Society of America weed biology survey. Weed Sci. 45:343-348.

Probert, R.J. and M. Black. 1992. The role of temperature in germination ecophysiology, $\mathrm{p}$. 285-325. In: M. Fenner (ed.). Seeds: The ecology of regeneration in plant communities. $\mathrm{CAB}$ Intl., Wallingford, U.K.

Ross, M.A. and C.A. Lembi. 1999. Weed life cycles and management, p. 220-255. In: Applied weed science. Prentice Hall, Upper Saddle River, N.J.

Twentyman, J.D. 1974. Environmental control of dormancy and germination in the seeds of Cenchrus longispinus (Hack.) Fern. Weed Res. 14:1-11. 